\title{
Metamorphic Age Comparison and Its Implications between the Zuoquan and Zanhuang Complexes in the Central North China Craton, Based on LA-ICP-MS Zircon U-Pb Dating
}

\author{
Ling-Ling Xiao ${ }^{1,2, *}$ and Min-Hua Chen ${ }^{3}$ \\ 1 Key Laboratory of Ministry of Education for Efficient Mining and Safety of Metal Mines, School of Civil and \\ Resource Engineering, University of Science and Technology Beijing, Beijing 100083, China \\ 2 State Key Laboratory of Continental Dynamics, Department of Geology, Northwest University, \\ Xi'an 710069, China \\ 3 Chengdu Center of China Geological Survey, Chengdu 610081, China; cminhua@foxmail.com \\ * Correspondence: xiaolingling@ustb.edu.cn
}

Received: 7 November 2019; Accepted: 11 December 2019; Published: 13 December 2019

check for updates

\begin{abstract}
The Trans-North China Orogen (TNCO) is well-known as an early Precambrian orogenic belt in the North China Craton (NCC). Three meaningful groups of metamorphic ages have been reported in the metamorphic complexes throughout the TNCO, including c. $1.85 \mathrm{Ga}$, c. $1.95 \mathrm{Ga}$, and c. $2.5 \mathrm{Ga}$. The spatial distributions and relationships of these ages provide notable insight into the formation timing and tectonic evolution of the NCC basement. The Zuoquan and Zanhuang complexes are exposed in the south-central TNCO and are adjacent to the Eastern Block. In order to place new constraints on the timing of two phases of metamorphism that occurred in the complexes, combined $\mathrm{U}-\mathrm{Pb}$ and rare earth element analyses were performed on zircons from different types of metamorphic rocks. Uranium- $\mathrm{Pb}$ zircon dating in this study shows that two groups of metamorphic ages of 1.88-1.85 Ga and 2.48-2.46 Ga were commonly recorded by metamorphic rocks in the Zanhuang and Zuoquan complexes, respectively. Our previous geochronological studies showed that metamorphic ages of c. $2.51 \mathrm{Ga}$ and c. $1.90 \mathrm{Ga}$ were locally recorded in the Zanhuang and Zuoquan complexes, respectively. These data indicate that metamorphic rocks in the two complexes underwent at least two phases of metamorphism, i.e., 2.51-2.46 Ga (Phase I) and 1.90-1.85 Ga (Phase II). In combination with previous studies regarding reaction microstructures, metamorphic pressure-temperature paths, and geochronology, the Phase II metamorphic ages are interpreted to be linked to the collision between the Western and Eastern Blocks along the TNCO between $1.97 \mathrm{Ga}$ and $1.80 \mathrm{Ga}$, whereas the Phase I metamorphic ages, as a result of an earlier and extensive tectono-thermal event that occurred in the Eastern and Western Blocks of the NCC, were related to underplating of mantle-derived magma. It is inferred that the rocks with c. 2.51-2.46 Ga metamorphic ages in the two complexes formed in the Eastern Block and underwent regional metamorphism during that period, and then were tectonically involved in the TNCO and experienced c. 1.90-1.85 Ga metamorphism. Metamorphic peaks occurred at different crustal levels in the orogen, resulting in distinct metamorphic ages and peak conditions preserved by metamorphic rocks in the two complexes.
\end{abstract}

Keywords: zircon LA-ICP-MS; Zuoquan; Zanhuang; Trans-North China Orogen; North China Craton 


\section{Introduction}

The Precambrian basement of the North China Craton (NCC) is considered to have formed through the amalgamation of several microblocks; however, there is disagreement regarding the timing of the main amalgamation [1-9]. Did the current NCC form at $2.5 \mathrm{Ga}, 1.95 \mathrm{Ga}$, or $1.85 \mathrm{Ga}$ ? A model proposed by Zhao et al. $(1998,2005,2012)[2,3,10]$ attracted considerable attention due to it being the only study that considered metamorphic pressure-temperature $(\mathrm{P}-\mathrm{T})$ paths together with metamorphic geochronology. In their interpretation, the NCC basement was thought to have formed through three collisional stages and was divided into three major parts, namely, the Western Block (WB), the Eastern Block (EB), and the Trans-North China Orogen (TNCO), which separates the blocks (Figure 1a). The majority of Archean metamorphic rocks from the WB and EB recorded counterclockwise P-T paths and c. 2.5 Ga metamorphic ages, which were thought to be related to the underplating of large amounts of mantle-derived magma, whereas metamorphic complexes exposed in the three orogenic belts showed clockwise $\mathrm{P}-\mathrm{T}$ paths related to continental collisions $[2,3,10]$. The first-stage collision occurred between the Yinshan and Ordos Blocks along the Khondalite Belt, forming the $\mathrm{WB}$ at c. $1.95 \mathrm{Ga}$. The second-stage collision occurred between the Longgang and Nangrim Blocks along the Jiao-Liao-Ji Belt, forming the EB at c. $1.90 \mathrm{Ga}$. The final, but most major, collision occurred between the WB and EB along the TNCO at c. $1.85 \mathrm{Ga}$, forming the entire NCC Precambrian basement $[2,3,10]$. Several Precambrian metamorphic complexes are exposed in the TNCO, including the Taihua, Zhongtiao, Dengfeng, Lüliang, Zuoquan, Zanhuang, Fuping, Wutai, Hengshan, Huai'an, Xuanhua, and Chengde complexes, from south to north. These complexes commonly recorded the $c$. $1.85 \mathrm{Ga}$ metamorphic ages, and there is agreement that the complexes were involved in the tectonic cycle of subduction-collision-uplift of the TNCO; [11-15] and references therein. 


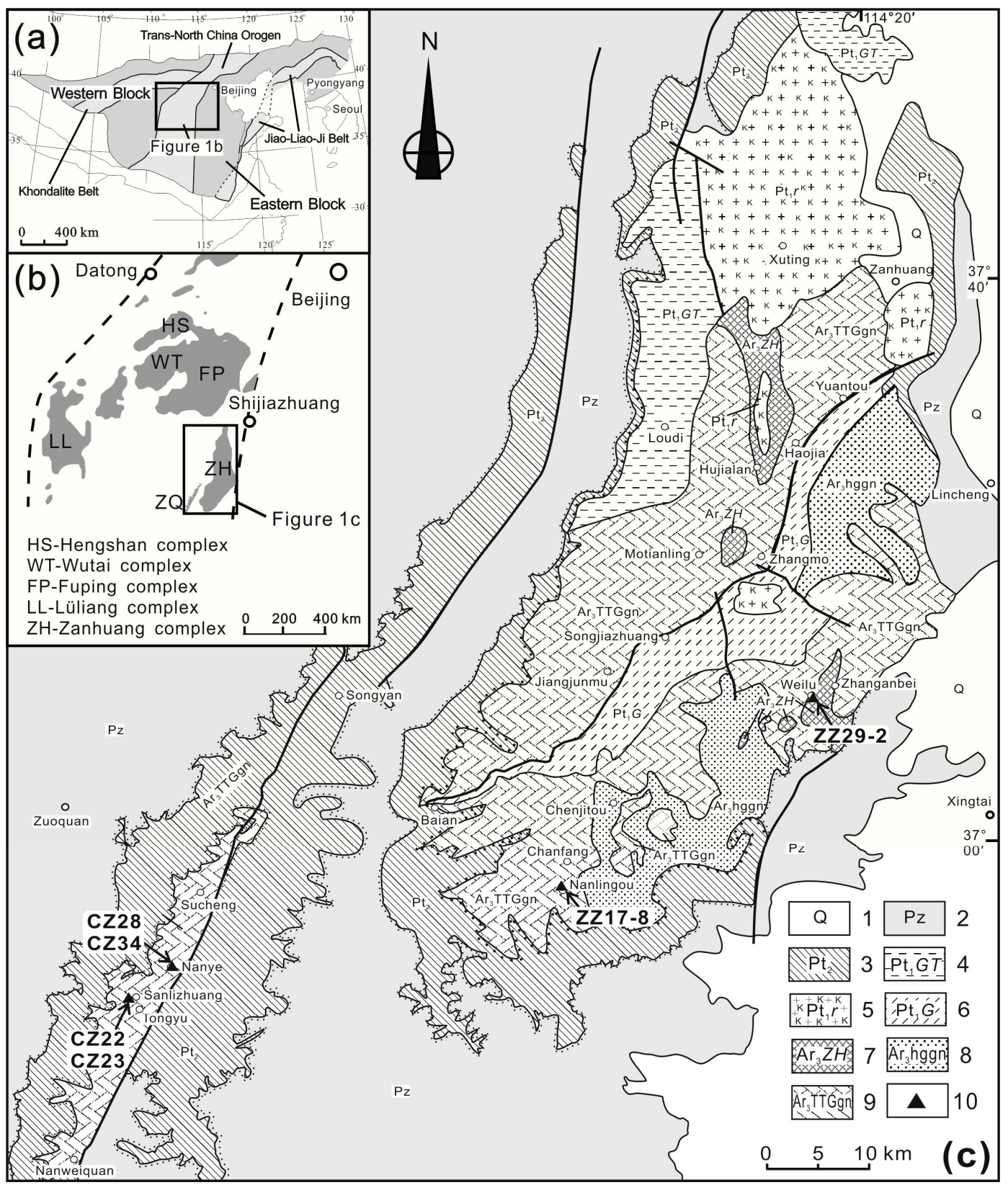

Figure 1. (a) Sketch map of the North China Craton (NCC) (modified after Zhao et al., 2005, 2012 [3,10]). (b) Sketch map of the Trans-North China Orogen (TNCO), showing the locations of the Zuoquan and Zanhuang complexes (modified after Zhao et al., 2001 [16]). (c) Geological sketch map of the Archean-Paleoproterozoic Zuoquan and Zanhuang metamorphic complexes (modified after Yang et al. 2011 [17]). Sample locations are shown on the map. 1: Quaternary; 2: Paleozoic strata; 3: Mesoproterozoic Changcheng Group; 4: Paleoproterozoic Gantaohe Group; 5: Xuting Granite; 6: Paleoproterozoic Guandu Group; 7: Neoarchean Zanhuang Group; 8: Neoarchean Monzogranite gneiss; 9: Neoarchean trondhjemite-tonalite-granodiorite (TTG) gneiss; 10: sample locations.

However, more metamorphic ages ranging between c. 1.97 and $1.90 \mathrm{Ga}$ have been reported in complexes throughout the TNCO $[15,18-36]$. There is agreement that the TNCO was involved in a complicated and protracted tectonic process that started as early as c. $1.97 \mathrm{Ga}$ and lasted until c. $1.80 \mathrm{Ga}[15,18-27,29-37]$. It is believed that the metamorphic ages between c. $1.97 \mathrm{Ga}$ and c. $1.80 \mathrm{Ga}$ represent different stages of the same metamorphism. However, the complexes exposed in the different segments of the TNCO have distinct and irregular peak metamorphic ages; thus, confirming the timing 
of the main collision between the WB and EB has been difficult. Some interpretations state that the major collision and crustal thickening in the Henshan-Wutai-Fuping area occurred at c. $1.95 \mathrm{Ga}$ and was followed by exhumation and cooling from c. 1.93 to $1.80 \mathrm{Ga}[25-27,31,32,37,38]$. Our previous studies showed that the crustal thickening in the Lüliang complex began at c. $1.96 \mathrm{Ga}$ and the subsequent uplift occurred after $1.89 \mathrm{Ga}[33,34]$. An alternative suggestion was made in the last two years [28,39], describing an updated interpretation of metamorphic ages in the Hengshan-Wutai complexes. The ages from 1.97 to $1.80 \mathrm{Ga}$ were thought to represent two metamorphic phases that occurred at c. $1.95 \mathrm{Ga}$ and c. $1.85 \mathrm{Ga}$, respectively, and were caused by two separately tectonic events. The tectonic event of c. $1.95 \mathrm{Ga}$ was related to a continental collision, whereas that of c. $1.85 \mathrm{Ga}$ resulted from within-plate deformation. The final exhumation of the high-grade rocks formed during the $\mathrm{c}$. $1.95 \mathrm{Ga}$ orogenic event were caused by the c. $1.85 \mathrm{Ga}$ deformation/metamorphic event.

Metamorphic ages ranging from between c. 2.54 and $2.40 \mathrm{Ga}$ were locally reported in the TNCO, such as in the Zanhuang, Zuoquan, Fuping, and Chengde complexes [12,40-44]. Similar metamorphic ages in the NCC were interpreted to be related to underplating of large amounts of mantle-derived magma in the WB and EB $[2,3,10]$ or the amalgamation of the Archean microcontinents $[4,5,7-9,44,45]$. Some studies of the latter showed that the c. $2.5 \mathrm{Ga}$ amalgamation resulted in the formation of much of the current NCC [4,5,7-9]. Another interpretation was that the Fuping Arc was already part of the EB at c. $2.5 \mathrm{Ga}[44,45]$; the subsequent west-dipping subduction and collision with the WB occurring at 1.90-1.85 Ga resulted in the final NCC amalgamation.

Therefore, to thoroughly comprehend the formation of the NCC basement, it is important to discriminate effects of the c. $2.5 \mathrm{Ga}$ regional metamorphism from those of events that occurred during the period c. $1.97-1.80 \mathrm{Ga}$ in the TNCO.

The Zuoquan and Zanhuang complexes are major components of the TNCO [46]. Based on zircon $\mathrm{U}-\mathrm{Pb}$, monazite $\mathrm{Th}-\mathrm{U}-\mathrm{Pb}$, and mineral ${ }^{40} \mathrm{Ar} /{ }^{39} \mathrm{Ar}$ dating, high-resolution geochronological analyses indicated that two groups of metamorphic ages (2.51-2.48 Ga and 1.90-1.80 Ga) were both recorded by their Precambrian metamorphic rocks [12,15,43,44,47-51]. However, it is currently unclear whether the c. $2.5 \mathrm{Ga}$ metamorphic rocks belonged to unrelated Archaean microblocks or pieces of the Western or Eastern Blocks that were tectonically reworked during the Paleoproterozoic era. Therefore, this contribution addresses the petrology and metamorphic age of different rock types throughout the two complexes, with the aim of understanding the spatial distribution and relationship of the two groups of metamorphic ages in the Zuoquan and Zanhuang complexes.

\section{Geological Setting}

The Zuoquan and Zanhuang metamorphic complexes are both situated in the south-central segment of the TNCO in the NCC. They are adjacent to the western boundary of the Eastern Block (Figure 1a,b). The Zuoquan complex lies to the southwest of the Zanhuang complex (Figure 1c). The complexes are mainly composed of diverse early Precambrian trondhjemite-tonalite-granodiorite (TTG) gneisses, a supracrustal assemblage, and monzonitic and potassic (MP) gneisses and granites. The locally exposed supracrustal assemblage was previously known as a part of the Zanhuang Group [52] but was recently subdivided into the Neoarchean Zanhuang Group and Paleoproterozoic Guandu Group [17,53]. The Neoarchean Zanhuang Group and Paleoproterozoic Guandu Group are unconformably overlain by sedimentary rocks of the Paleoproterozoic Gantaohe Group (Figure 1c). The Gantaohe Group underwent greenschist to low-amphibolite facies metamorphism [54,55]. The Neoarchean Zanhuang Group and Paleoproterozoic Guandu Group were mostly metamorphosed at upper amphibolite facies to granulite facies conditions. The highest pressures and temperatures of the metamorphic peaks are up to $12.3 \mathrm{kbar}$ and $830{ }^{\circ} \mathrm{C}$ in the Zanhuang area, whereas they are approximately $9.4 \mathrm{kbar}$ and $670^{\circ} \mathrm{C}$ in the Zuoquan area, respectively [12,46]. The Neoarchean Zanhuang Group consists of various gneisses and small amounts of metapelites, marbles, and amphibolites, while the Paleoproterozoic Guandu Group mainly comprises quartzites, mica schists, and marbles [17]. Marbles and sillimanite-/kyanite-bearing metapelites (Figure 2) are locally exposed in the south-central 
Zanhuang complex. Amphibolites exposed in the two complexes occur as layers or lens-shaped boudins within metapelites and/or felsic gneisses with consistent gneissosity. Schists and marbles interbedded with felsic gneiss and consistent foliation was recorded in these rocks. Magnetite-rich schists, quartzites, and gneisses were found locally in the two complexes and even formed small iron ore deposits. Banded magnetite commonly occurs in these rocks.
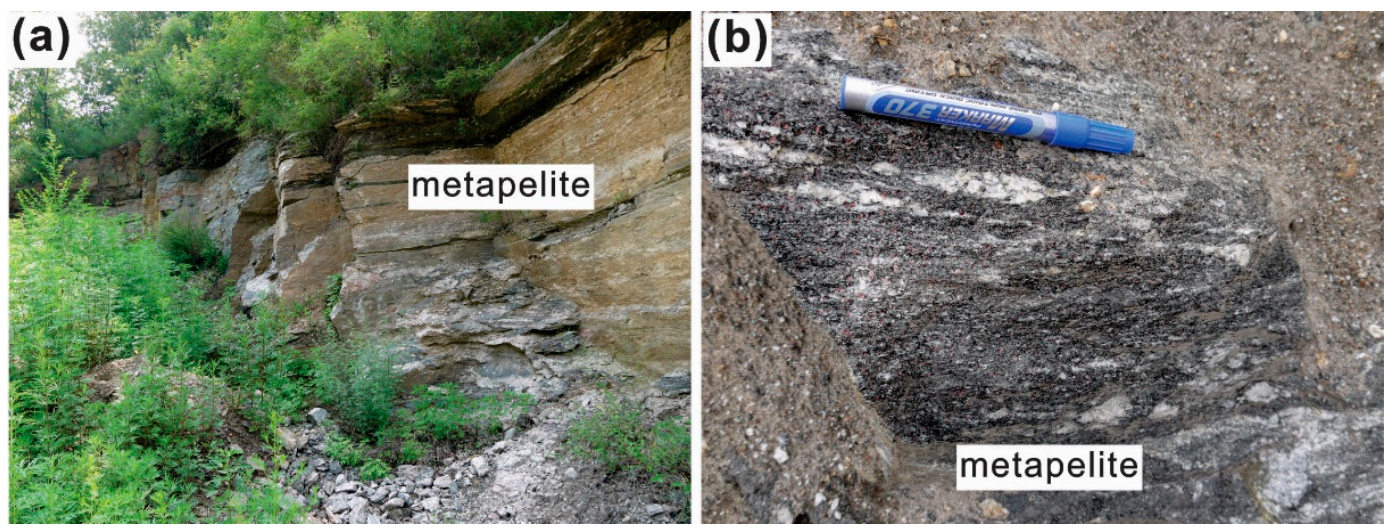

Figure 2. Photographs of outcrop (a) and hand specimen (b) of metapelite samples, ZZ17-8 and ZZ29-2, in the Zanhuang metamorphic complex.

Previous studies showed that three generations of metamorphic mineral assemblages, formed at prograde, peak, and retrograde stages, respectively, were identified in the metapelites, amphibolites, and gneisses $[12,46,56,57]$. These rocks yielded consistent clockwise P-T paths with nearly isothermal decompression (ITD) retrograde segments $[12,46,56,57]$. Such metamorphic P-T paths were thought to be related to a subduction-collisional orogeny, followed by a rapid post orogenic uplift [58,59].

Published isotopic analyses indicated that the U-Pb detrital zircon ages of the Neoarchean Zanhuang Group and Paleoproterozoic Guandu Group mainly ranged between 2.57 and $2.45 \mathrm{Ga}[44,45,60,61]$. Our recent studies showed that a minor age population of 2.7-2.6 Ga was also recorded by various types of metamorphic rocks of the two groups [62]. The detrital zircons from the Gantaohe Group exhibited a major age population of 2.55-2.50 Ga with minor age populations of c. $2.7 \mathrm{Ga}$ and c. $2.1 \mathrm{Ga}$, and this group was interpreted to have formed at c. 2.1 Ga [54]. TTG and MP gneisses of the Zanhuang complex commonly formed during 2.51-2.50 Ga [60,63]. In recent years, some c. 2.7 Ga TTG gneisses were reported both in the Zanhuang and Zuoquan complexes [53,62,64].

\section{Sample Selection and Analytical Methods}

\subsection{Sample Selection}

Zircon $\mathrm{U}-\mathrm{Pb}$ dating of six representative samples is reported here, including four samples (CZ22, CZ23, CZ28, and CZ34) from the Zuoquan complex and two samples (ZZ17-8 and ZZ29-2) from the Zanhuang complex. The sample rocks are medium- to coarse-grained and commonly show crystalloblastic textures and schist/gneissic structures.

Samples CZ22 and CZ23 were obtained from a quarry site in Sanlizhuang village within the Zuoquan complex (Figure 1c). The former was a magnetite-bearing biotite-hornblende schist and mainly consisted of biotite (30-35\%), hornblende (25-30\%), quartz (25-30\%), magnetite (3-5\%), and clinopyroxene (0-1\%) (Figure 3a). The latter was a magnetite-hornblende-quartz schist with a metamorphic mineral assemblage of quartz (45-50\%), magnetite (30-35\%), and hornblende (10-15\%) (Figure 3b). Magnetite and quartz were banded in these samples (Figure 3a,b). Samples CZ28 and CZ34 were collected from a quarry site in Nanye village within the Zuoquan complex (Figure 1c). They were garnet-bearing hornblende-biotite-plagioclase gneiss with a mineral assemblage of plagioclase $(30-35 \%)$, quartz $(30-35 \%)$, biotite $(10-15 \%)$, garnet $(5-10 \%)$, hornblende $(5-15 \%)$, and magnetite 
(2-5\%) (Figure 3c,d). Samples ZZ17-8 and ZZ29-2 were collected from different outcrops in Nanlingou and Weilu villages in the south-central region of the Zanhuang complex (Figure 1c). They were coarsely-grained garnet-bearing metapelites with a metamorphic peak mineral assemblage of quartz (40-50\%), biotite $(15-20 \%)$, garnet (5-20\%), kyanite (2-20\%), plagioclase $(0-5 \%)$, and magnetite $(0-1 \%)$ (Figure 3e,f). The garnet porphyroblasts contained mineral inclusions of quartz, biotite, and magnetite (Figure $3 \mathrm{e}, \mathrm{f}$ ) that formed during the prograde and/or peak metamorphic stage. The prograde inclusions were tiny and concentrated in the core of the garnet (Figure 3e), whereas the peak inclusions were bigger in size and were scattered within the garnet (Figure $3 \mathrm{e}, \mathrm{f}$ ).
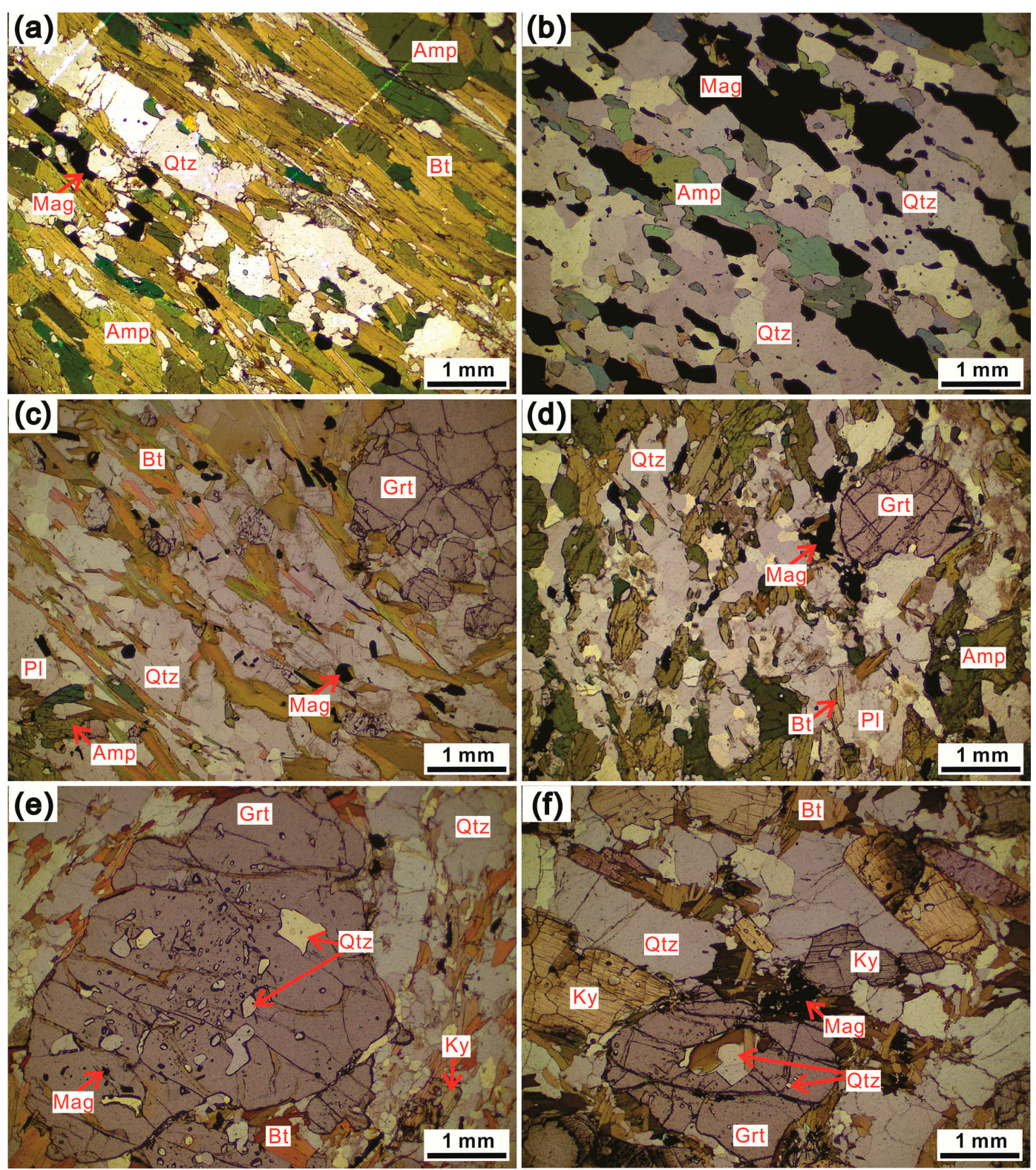

Figure 3. Photomicrographs of the Zuoquan and Zanhuang samples. (a) Sample CZ22; (b) sample CZ23; (c) sample CZ28; (d) sample CZ34; (e) sample ZZ17-8; (f) sample ZZ29-2. See the text for details.

\subsection{Analytical Methods}

All samples were processed using standard heavy liquid and magnetic separation techniques after crushing the rocks. More than 250 zircon grains from each sample were hand-picked and mounted on an epoxy mount. Zircons were then polished to approximately half of their original size and 
photographed in reflected and transmitted light. The internal texture of the zircons was studied by performing cathodoluminescence $(\mathrm{CL})$ imaging to identify potential sites for dating analysis. The CL images were obtained using a JSMIT100 scanning electron microprobe connected to a GATAN MINICL system at Wuhan Sample Solution Analytical Technology Co., Ltd., Wuhan, China. The imaging conditions included an electric field voltage of $10-13 \mathrm{kV}$ and a tungsten filament with a current of $80-85 \mu \mathrm{A}$.

Uranium- $\mathrm{Th}-\mathrm{Pb}$ isotopic ratio and trace element analyses of zircon were conducted using a $193 \mathrm{~nm}$ GeolasHd laser ablation (LA) system, inductively coupled with plasma mass spectrometry (ICP-MS; Agilent 7900) at Wuhan Sample Solution Analytical Technology Co., Ltd., Wuhan, China. Helium was applied as a carrier gas. Argon was used as the make-up gas and mixed with the carrier gas via a T-connector before entering the ICP. The laser energy was $80 \mathrm{~mJ}$. The spot size and frequency of the laser were set to $32 \mu \mathrm{m}$ and $5 \mathrm{~Hz}$, respectively, for the LA-ICP-MS measurements. Zircon standard 91500 [65] was employed as an external standard for the correction of the $\mathrm{U} / \mathrm{Pb}$ fractionation. Zircon GJ-1 [66] was used as the monitoring standard. The standard glass NIST 610 and element Si were used as an external standard and internal standard, respectively, to determine the elemental concentration. Each analysis incorporated a background acquisition of approximately 20-30 s, followed by $50 \mathrm{~s}$ of data acquisition from the sample. The analytical data were processed using the ICPMSDataCal program (version 10.8, China University of Geosciences, Wuhan, China). The concordia plots and age calculations were performed using the Isoplot/Ex v. 3.23 program [67]. The error ranges of individual analyses were quoted at the $1 \sigma$ level. The upper intercept ages and the weighted mean ages for the aggregated ${ }^{207} \mathrm{~Pb} /{ }^{206} \mathrm{~Pb}$ analyses were presented with uncertainties at the $2 \sigma$ and $95 \%$ confidence levels, respectively. The zircon $\mathrm{U}-\mathrm{Pb}$ analytical data are listed in Table S1. The rare earth element (REE) contents of the zircon spots are listed in Table S2.

\section{Results}

Zircon grains extracted from all of the samples in the Zuoquan and Zanhuang complexes were anhedral and ranged from 30 to $200 \mu \mathrm{m}$ in length.

\subsection{Zircon Dating of Samples in the Zuoquan Complex}

\subsubsection{Magnetite-Bearing Biotite-Hornblende Schist Sample}

Zircons of sample CZ22 showed variable luminescence and disturbed oscillatory zoning preserved in the CL images. Some grains showed a relatively homogeneous internal texture in their cores (Figure 4a).

Twenty-one spots were analyzed on relatively homogeneous domains of 21 zircon grains (Figure 4a). The Th and U contents and Th/U ratios of the zircon spots ranged from 53 to $160 \mathrm{ppm}, 96$ to $369 \mathrm{ppm}$, and 0.31 to 0.69 , respectively (Table S1; Figure 4 b). All spots showed weakly negative europium anomalies and high heavy rare earth element (HREE) enrichment in chondrite-normalized REE distribution patterns (Figure 4c). Twenty-one spot analyses yielded ${ }^{207} \mathrm{~Pb} /{ }^{206} \mathrm{~Pb}$ ages ranging from 2377 to $2532 \mathrm{Ma}$ (Figure 4d). Eighteen available analyses were plotted near the concordia curve, yielding a weighted mean ${ }^{207} \mathrm{~Pb} /{ }^{206} \mathrm{~Pb}$ age of $2471 \pm 14 \mathrm{Ma}$ (mean square weighted deviates $(\mathrm{MSWD})=1.4$; Figure 4e). 

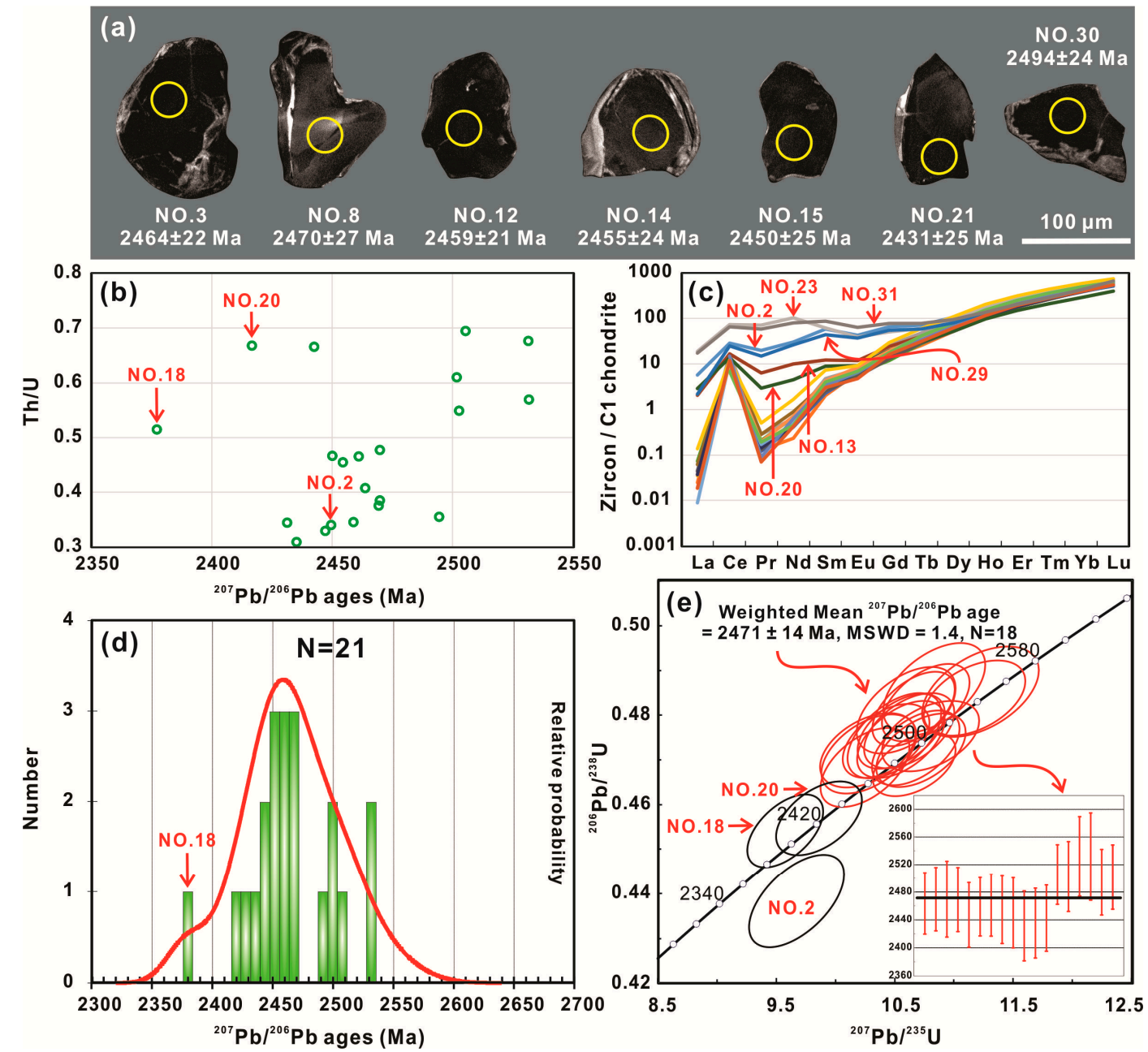

Figure 4. Cathodoluminescence (CL) images (a), relationship diagram of $\mathrm{Th} / \mathrm{U}$ ratios and ${ }^{207} \mathrm{~Pb} /{ }^{206} \mathrm{~Pb}$ ages (b), chondrite-normalized rare earth element (REE) distribution pattern diagrams $(\mathbf{c}),{ }^{207} \mathrm{~Pb} /{ }^{206} \mathrm{~Pb}$ age frequency distribution histogram (d), and $\mathrm{U}-\mathrm{Pb}$ concordia diagram (e) for the analyzed zircons from sample CZ22. The circles represent the spots from which LA-ICP-MS measurements were taken. The numbers refer to the analytical data listed in Table S1.

\subsubsection{Magnetite-Hornblende-Quartz Schist Sample}

Zircons extracted from sample CZ23 were characterized by irregular luminescence; some domains showed a bright luminescence in the CL images (Figure 5a).

Fifty-one analyses were conducted from 48 zircon grains. The Th and $\mathrm{U}$ contents and $\mathrm{Th} / \mathrm{U}$ ratios of the zircon spots ranged from 6 to 171 ppm, 30 to 294 ppm, and 0.18 to 0.90 (Table S1; Figure 5b), respectively. All of the spots showed steep REE patterns and a high HREE concentration, and most had no europium anomalies (Figure $5 \mathrm{c}$ ). The ${ }^{207} \mathrm{~Pb} /{ }^{206} \mathrm{~Pb}$ ages of all the spots ranged from 2165 to $2653 \mathrm{Ma}$ (Figure $5 \mathrm{~d}$ ). Five spots on the bright domains yielded ${ }^{207} \mathrm{~Pb} /{ }^{206} \mathrm{~Pb}$ ages ranging from 2316 to $2519 \mathrm{Ma}$ (No.14, 22, 26, 31, and 34; Table S1). Forty-seven available analytical spots were plotted near the concordia curve, defining a weighted mean ${ }^{207} \mathrm{~Pb} /{ }^{206} \mathrm{~Pb}$ age of $2473 \pm 10 \mathrm{Ma}(\mathrm{MSWD}=1.7$; Figure 5e). 

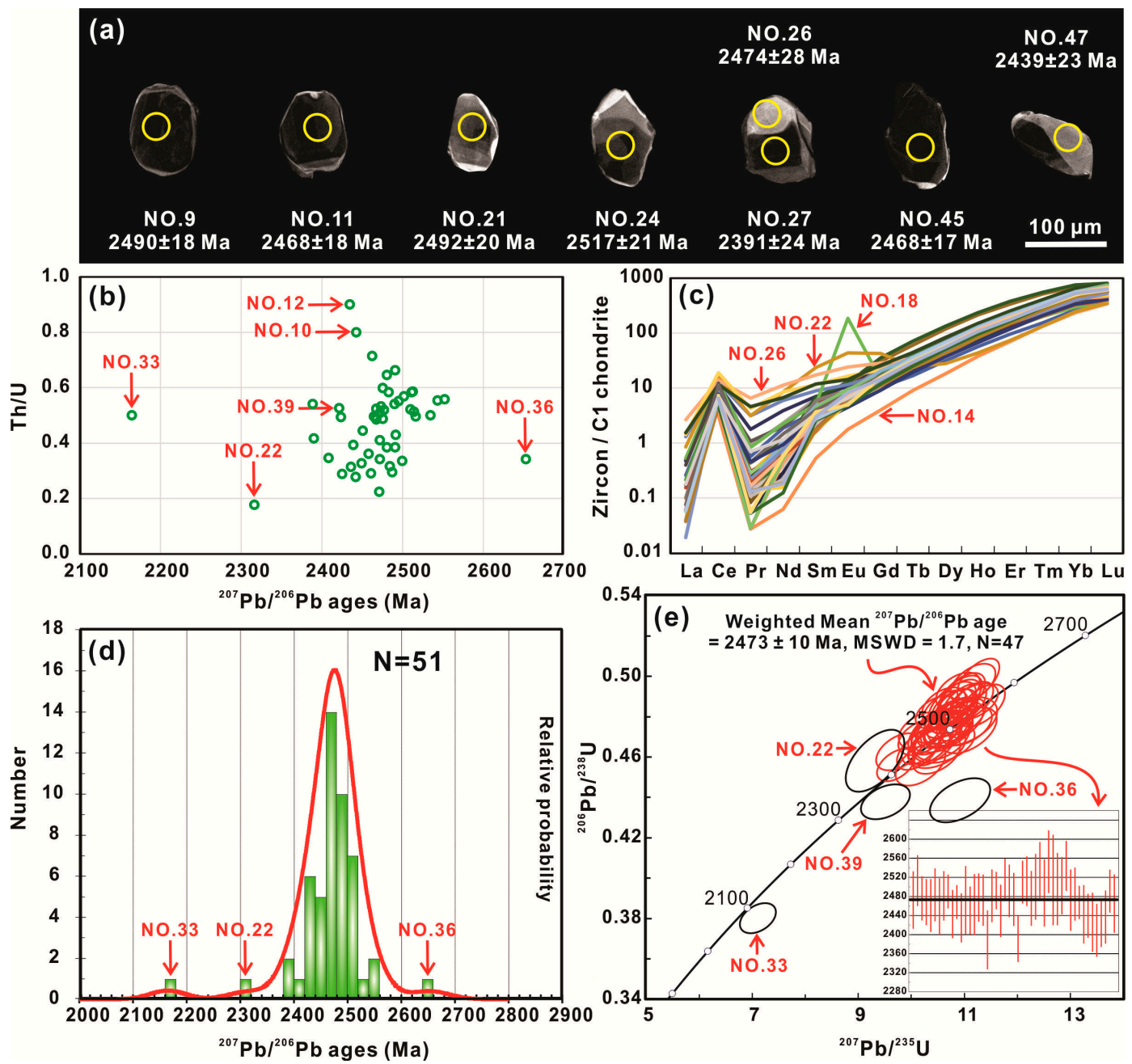

Figure 5. $C L$ images (a), relationship diagram of $\mathrm{Th} / \mathrm{U}$ ratios and ${ }^{207} \mathrm{~Pb} / 206 \mathrm{~Pb}$ ages (b), chondritenormalized REE distribution pattern diagrams $(\mathbf{c}),{ }^{207} \mathrm{~Pb} /{ }^{206} \mathrm{~Pb}$ age frequency distribution histogram (d), and $\mathrm{U}-\mathrm{Pb}$ concordia diagram (e) for the analyzed zircons from sample CZ23. The circles represent the spots from which LA-ICP-MS measurements were taken. The numbers refer to the analytical data listed in Table S1.

\subsubsection{Garnet-Bearing Hornblende-Biotite-Plagioclase Gneiss Samples}

Zircon grains separated from samples CZ28 and CZ34 showed a similar internal texture to that of sample CZ22, with variable luminescence and disturbed oscillatory zoning in the CL images (Figures $6 a$ and $7 a)$. Recrystallized zircon domains were analyzed, with most of them showing relatively homogeneous luminescence.

Twenty-eight spots were analyzed on 28 zircon grains of sample CZ28. Their components showed great variation in $U$ content, ranging from 280 to $1185 \mathrm{ppm}$. The Th content and Th/U ratios of the zircon spots ranged from 9 to $140 \mathrm{ppm}$ and 0.02 to 0.22, respectively (Table S1; Figure 6b). All of the spots showed a flat HREE pattern with a low HREE concentration, and most showed negative europium anomalies (Figure 6c). The ${ }^{207} \mathrm{~Pb} /{ }^{206} \mathrm{~Pb}$ ages of all analyses ranged from 1902 to $2517 \mathrm{Ma}$, but were mostly concentrated between 2403 and 2517 Ma (Figure 6d). All spot analyses defined a chord with an upper intercept age of $2473 \pm 14 \mathrm{Ma}$ in the concordia diagram (MSWD =1.3; Figure 6e). Eighteen available analytical spots yielded a weighted mean ${ }^{207} \mathrm{~Pb} /{ }^{206} \mathrm{~Pb}$ age of $2477 \pm 13 \mathrm{Ma}$ (MSWD $=1.3$; Figure 6e). 

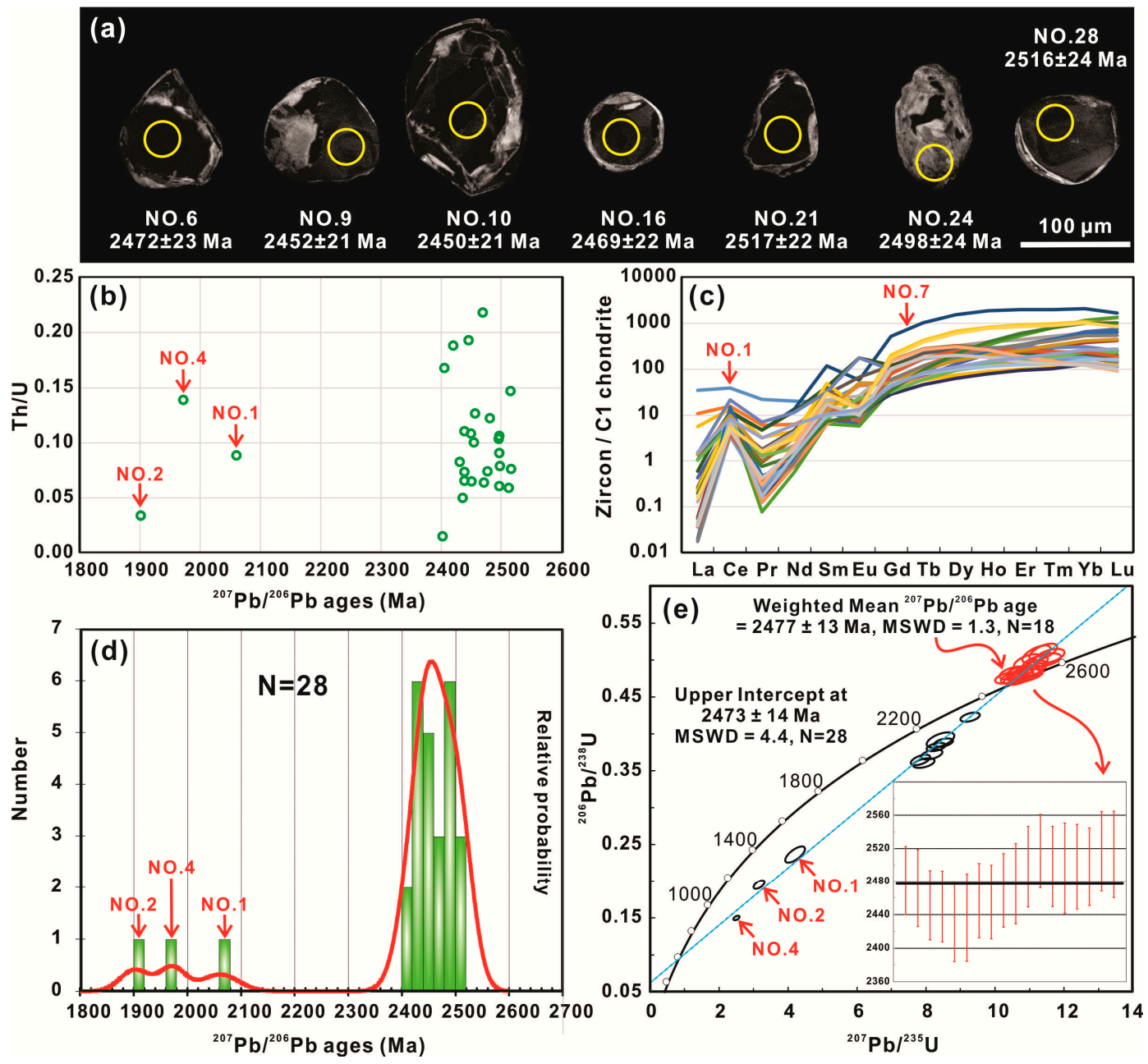

Figure 6. $C L$ images (a), relationship diagram of $\mathrm{Th} / \mathrm{U}$ ratios and ${ }^{207} \mathrm{~Pb} /{ }^{206} \mathrm{~Pb}$ ages (b), chondritenormalized REE distribution pattern diagrams $(\mathrm{c}),{ }^{207} \mathrm{~Pb} /{ }^{206} \mathrm{~Pb}$ age frequency distribution histogram (d), and $\mathrm{U}-\mathrm{Pb}$ concordia diagram (e) for the analyzed zircons from sample CZ28. The circles represent the spots from which LA-ICP-MS measurements were taken. The numbers refer to the analytical data listed in Table S1.

Thirty-six analyses were dated from 36 zircon grains of sample CZ34. The Th and U contents and $\mathrm{Th} / \mathrm{U}$ ratios of the zircon spots were 13-164 ppm, 100-936 ppm, and 0.01-0.48 (Table S1; Figure 7b), respectively. Most of the spots showed a flat HREE pattern with negative europium anomalies (Figure $7 \mathrm{c}$ ). The ${ }^{207} \mathrm{~Pb} /{ }^{206} \mathrm{~Pb}$ ages of all spots ranged from 2406 to $2539 \mathrm{Ma}$ (Figure $7 \mathrm{~d}$ ). Thirty-five available analyses yielded a weighted mean ${ }^{207} \mathrm{~Pb} /{ }^{206} \mathrm{~Pb}$ age of $2462 \pm 12 \mathrm{Ma}(\mathrm{MSWD}=2.0$; Figure $7 \mathrm{e}$ ). 

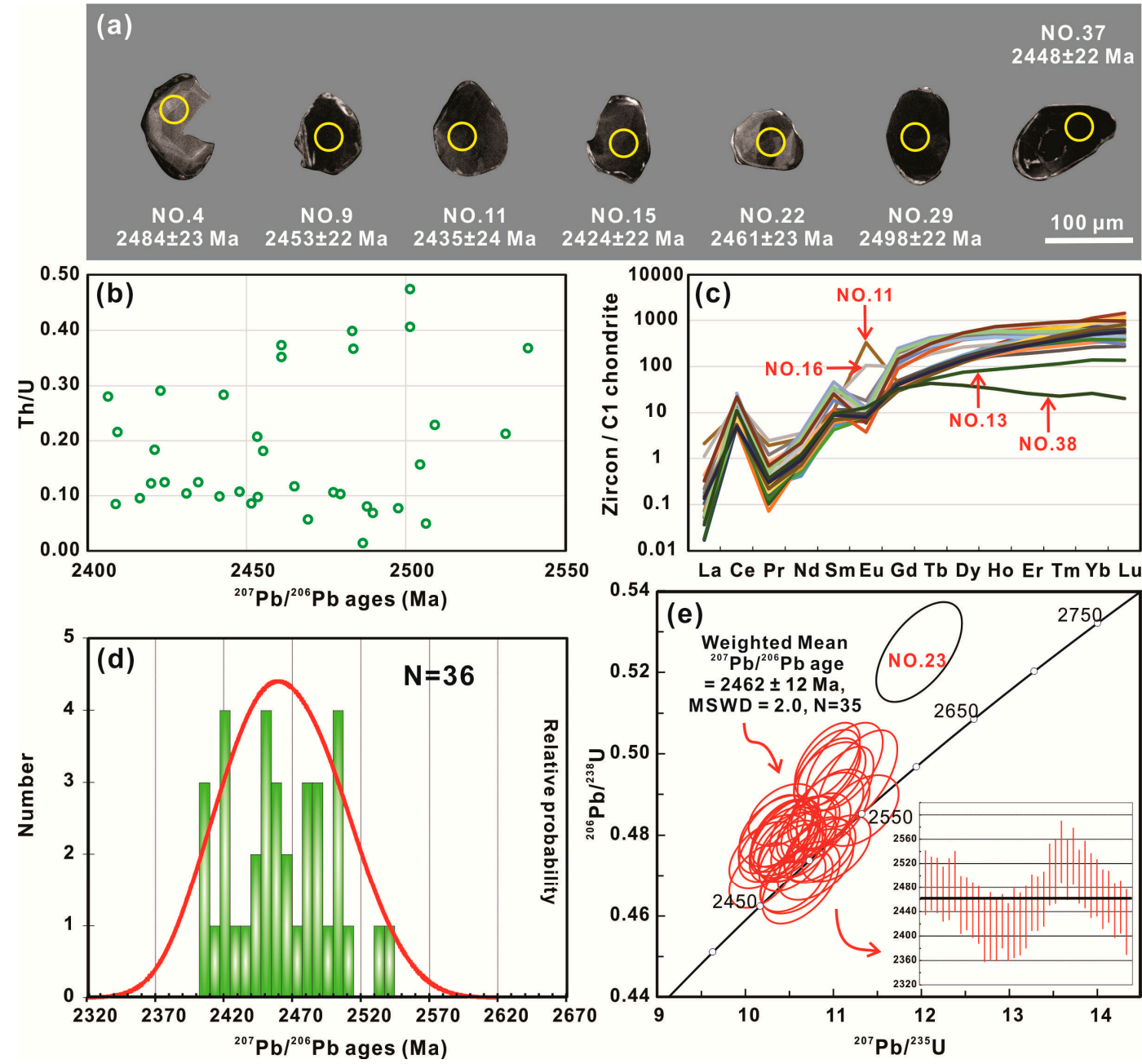

Figure 7. CL images (a), relationship diagram of $\mathrm{Th} / \mathrm{U}$ ratios and ${ }^{207} \mathrm{~Pb} / 206 \mathrm{~Pb}$ ages $(\mathbf{b})$, chondritenormalized REE distribution pattern diagrams $(\mathrm{c}),{ }^{207} \mathrm{~Pb} /{ }^{206} \mathrm{~Pb}$ age frequency distribution histogram (d), and U-Pb concordia diagram (e) for the analyzed zircons from sample CZ34. The circles represent the spots from which LA-ICP-MS measurements were taken. The numbers refer to the analytical data listed in Table S1.

\subsection{Zircon Dating of Samples in the Zanhuang Complex}

Two groups of zircons were recognized in garnet-bearing metapelite samples ZZ17-8 and ZZ29-2 based on variations in the internal textures observed in the CL images (Figures 8a and 9a). Some zircon grains showed a rim-core texture. The core domains showed variable luminescence with disturbed or blurred oscillatory zoning, and a few of them showed obvious oscillatory zoning, which were defined as Group 1 (i.e., No.26 in Figure 8a). The rim domains were characterized by a relatively homogeneous internal texture with low luminescence and defined as Group 2 (Figures 8a and 9a). Other zircon grains showed no rim-core texture, and the CL characteristics of these were similar to those of the Group 2 zircon domains (Figures 8a and 9a).

Thirty-eight analyses were completed using 38 zircons grains from sample ZZ17-8, including four zircon cores of Group 1 and 34 zircon grains and/or domains of Group 2. The Th and U contents of the zircon spots exhibited ranges of 60-310 ppm and 90-316 ppm for the Group 1 zircons and 0.5-27.1 ppm and 69-422 ppm for the Group 2 zircons, respectively (Table S1). The Th/U ratios of the Group 1 and Group 2 zircon spots ranged from 0.48 to 0.98 and 0.00 to 0.28 , respectively (Table S1; Figure $8 \mathrm{~b}$ ). Two groups of zircon spots showed distinct HREE contents in chondrite-normalized REE distribution patterns (Figure 8c), a steep pattern for Group 1, and a flat pattern for Group 2. The ${ }^{207} \mathrm{~Pb} /{ }^{206} \mathrm{~Pb}$ ages of 
Group 1 zircons ranged from 2450 to $2531 \mathrm{Ma}$, whereas those of Group 2 ranged from 1791 to $2455 \mathrm{Ma}$, but largely concentrated between 1791 and $1896 \mathrm{Ma}$ (Figure 8d). All of the Group 1 spots defined a weighted mean ${ }^{207} \mathrm{~Pb} /{ }^{206} \mathrm{~Pb}$ age of $2495 \pm 52 \mathrm{Ma}(\mathrm{MSWD}=1.8, \mathrm{n}=4$ ). Twenty-eight analyses of the Group 2 spots defined a chord with an upper intercept age of $1875 \pm 16 \mathrm{Ma}(\mathrm{MSWD}=2.0$ ) (Figure 8e) and yielded a weighted mean ${ }^{207} \mathrm{~Pb} /{ }^{206} \mathrm{~Pb}$ age of $1875 \pm 10 \mathrm{Ma}$ (MSWD $=1.5$; Figure 8e).

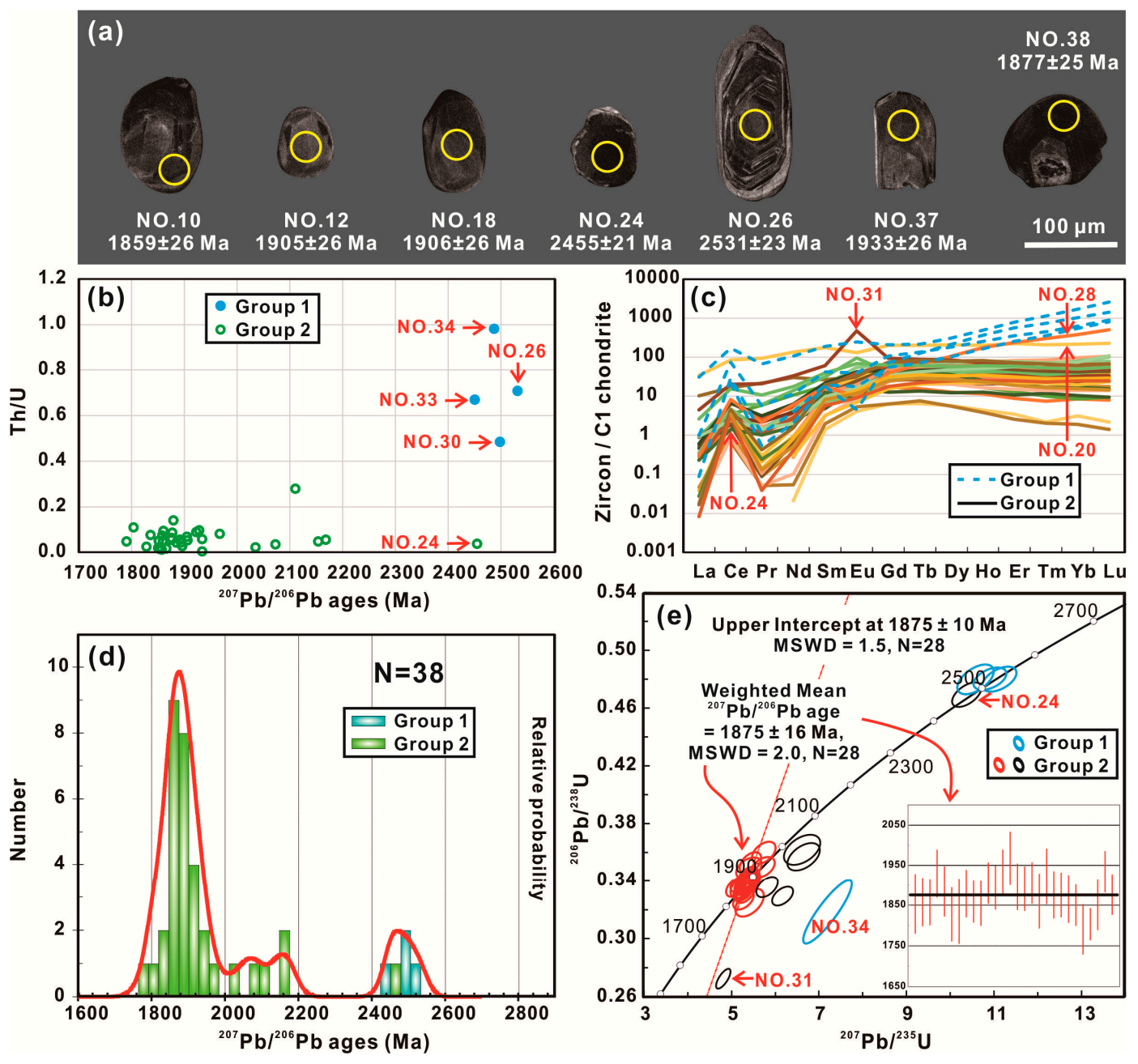

Figure 8. CL images (a), relationship diagram of $\mathrm{Th} / \mathrm{U}$ ratios and ${ }^{207} \mathrm{~Pb} /{ }^{206} \mathrm{~Pb}$ ages (b), chondritenormalized REE distribution pattern diagrams $(\mathbf{c}),{ }^{207} \mathrm{~Pb} /{ }^{206} \mathrm{~Pb}$ age frequency distribution histogram (d), and U-Pb concordia diagram (e) for the analyzed zircons from sample ZZ17-8. The circles represent the spots from which LA-ICP-MS measurements were taken. The numbers refer to the analytical data listed in Table S1.

Forty-five spots were analyzed on 29 grains and 16 rim domains of the Group 2 zircons from sample ZZ29-2. The Th and $\mathrm{U}$ contents and Th/U ratios of the zircon spots ranged from 0.3 to $5.0 \mathrm{ppm}$, 45 to $244 \mathrm{ppm}$, and 0.00 to 0.02 (Table S1; Figure 9b), respectively. Most spots exhibited no europium anomalies (Figure 9c). The HREEs of some analytical spots showed a flat pattern, while the others showed an oblique pattern (Figure 9c); however, there was no age distinction between the two types. The ${ }^{207} \mathrm{~Pb} /{ }^{206} \mathrm{~Pb}$ ages of 29 grains and 16 rim domains ranged from 1787 to $1933 \mathrm{Ma}$ and 1825 to $1928 \mathrm{Ma}$, respectively (Figure 9d). Forty-three available analyses yielded an upper intercept age of $1849 \pm 7 \mathrm{Ma}$ $\left(\mathrm{MSWD}=0.9\right.$ ) (Figure 9e) and defined a weighted mean ${ }^{207} \mathrm{~Pb} /{ }^{206} \mathrm{~Pb}$ age of $1858 \pm 11 \mathrm{Ma}(\mathrm{MSWD}=0.9$; Figure 9e). The two ages were similar and well within the error range. 

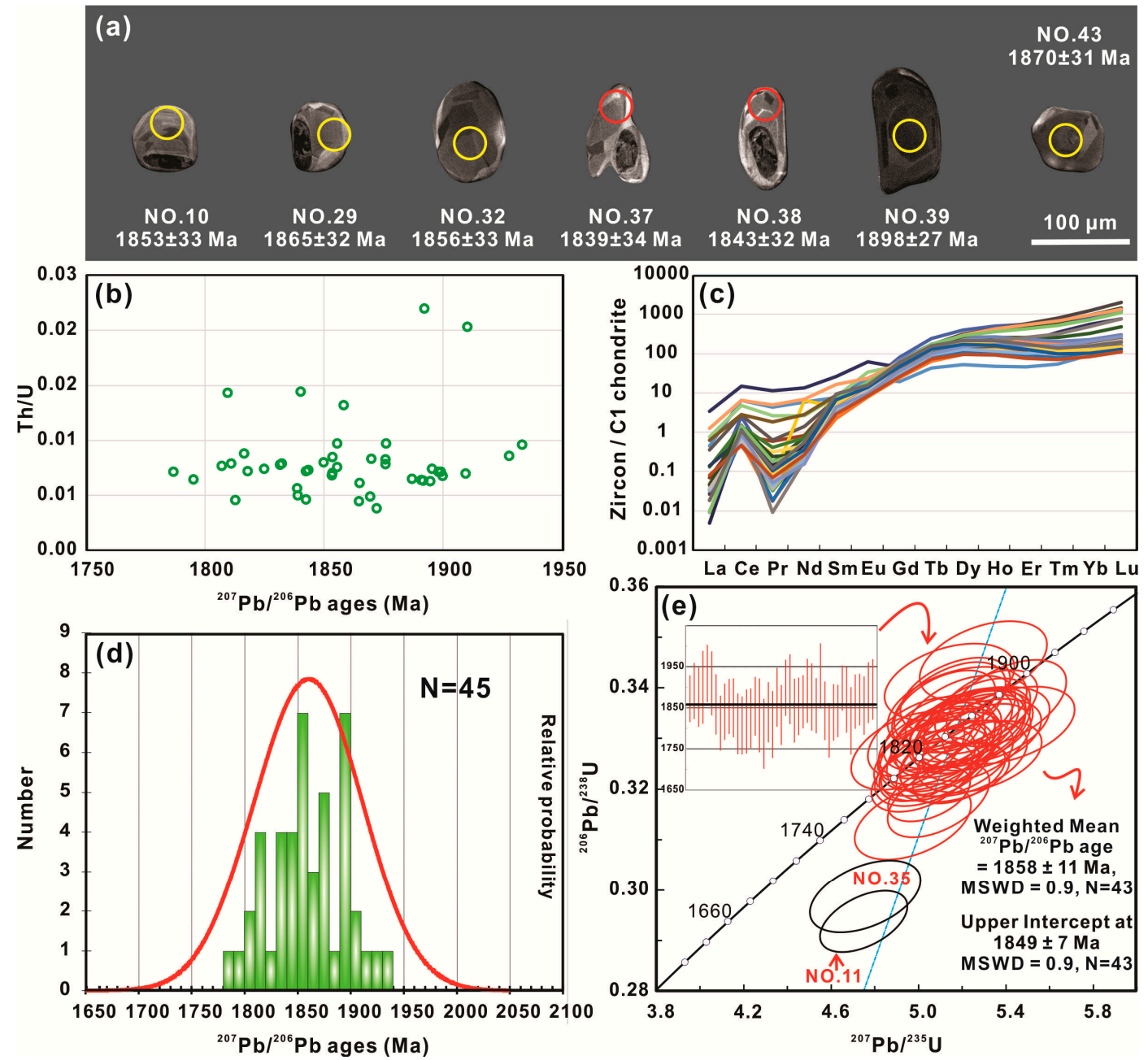

Figure 9. $C L$ images (a), relationship diagram of $\mathrm{Th} / \mathrm{U}$ ratios and ${ }^{207} \mathrm{~Pb} /{ }^{206} \mathrm{~Pb}$ ages (b), chondritenormalized REE distribution pattern diagrams $(\mathbf{c}),{ }^{207} \mathrm{~Pb} /{ }^{206} \mathrm{~Pb}$ age frequency distribution histogram (d), and U-Pb concordia diagram (e) for the analyzed zircons from sample ZZ29-2. The circles represent the spots from which LA-ICP-MS measurements were taken. The numbers refer to the analytical data listed in Table S1.

\section{Discussion}

\subsection{Characteristics of Metamorphic Zircons}

Metamorphic zircons are typically distinguished according to analyses of their grain shapes, CL images, REE patterns, and U/Th ratios. These grains are anhedral, elliptical, or subhedral-columnar in shape [68-72].

Making observations based on variations in the internal textures in the CL images is a ubiquitous and reliable method [68,72]. Metamorphic zircons include recrystallized zircons, that existed prior to metamorphism but were modified, and overgrowth or new growth zircons, which grew as a result of the metamorphic process [71,72]. The variety of internal textures in zircon CL images is extremely wide $[68,72,73]$, and three major types are listed as follows. (1) Type 1 zircons have no rim-core texture and are relatively homogeneous with low luminescence within a single domain. They generally show blurred cloudy zoning (i.e., ZZ29-2; No.32 in Figure 9a), irregular zoning (i.e., CZ23; Figure 5a), and sector or fir-tree zoning. These characteristics are typical of metamorphic origin [71,72]. (2) Type 2 zircons show no rim-core texture but have variable luminescence and disturbed oscillatory zoning (i.e., CZ28; Figure 6a). These characteristics are indicative of recrystallization during metamorphism [71,74]. 
(3) Type 3 zircons show rim-core texture. The cores are commonly of inherited origin with variable luminescence or igneous origin with visible oscillatory zoning, whereas the rims are as a result of metamorphic growth with similar characteristics to Type 1 zircons (i.e., ZZ29-2; No.10 and No.37 in Figure 9a) [71].

The REEs, especially the HREEs, can also be used to recognize metamorphic zircons [72]. Metamorphic zircons show patterns with significant REE fractionation and are enriched in light REE (LREE) in chondrite-normalized REE distribution patterns. The level of HREE enrichment of metamorphic zircons is based on the garnet content, the growth order of the garnet and the metamorphic zircon, and the recrystallization degree of the original zircon, in addition to the rock composition. This is mainly because garnets are generally a main host of HREEs in medium to high-grade mafic to pelitic metamorphic rocks, and HREEs prefer to fractionate into garnets during the metamorphic process [71,75]. Metamorphic zircons in garnet-free rocks show steep REE patterns with a high concentration of HREEs (i.e., CZ22 and CZ23; Figures 4c and 5c). In garnet-rich rocks, metamorphic zircons show a relatively flat HREE pattern if the garnets grew with or before the metamorphic zircons (i.e., CZ34 and ZZ17-8; Figures 7c and 8c). Sometimes, the HREE patterns vary between steep and flat, because recrystallizations result in the resetting of the chemical/isotopic system of different pre-existing zircons (i.e., CZ28 and ZZ29-2; Figures 6c and 9c). Conversely, if the garnets grew after the metamorphic zircons, their HREE patterns are similar to those of zircons in garnet-free rocks. Plagioclase is generally a main host of europium but is lacking in other REEs [76], thus plagioclase-rich rocks commonly show negative europium anomalies.

Although the $\mathrm{Th} / \mathrm{U}$ ratio is an easy-to-acquire and widely-used criterion for zircon classification [72], a low $\mathrm{Th} / \mathrm{U}$ ratio (i.e., less than 0.1 ) is not always shown by metamorphic zircons $[33,72,77-80]$. Metamorphic zircons can have Th/U ratios up to 0.8 (i.e., CZ23; Figure $5 b$ ), which could be attributed to the high protolith $\mathrm{Th} / \mathrm{U}$ ratios of the analyzed zircon domains or the whole rocks [80].

\subsection{Interpretation of Zircon $\mathrm{U}-\mathrm{Pb}$ Dating}

LA-ICP-MS zircon U-Pb dating performed in this study shows that distinct metamorphic ages were recorded by metamorphic rocks exposed in the Zuoquan and Zanhuang complexes.

Metamorphic ages between 2477 and 2462 Ma dominate in the Zuoquan complex. Schist samples yield ages of $2471 \pm 14 \mathrm{Ma}$ (CZ22) and $2473 \pm 10 \mathrm{Ma}$ (CZ23), and garnet-bearing gneiss samples yield ages of $2477 \pm 13 \mathrm{Ma}(\mathrm{CZ28})$ and $2462 \pm 12 \mathrm{Ma}$ (CZ34), are interpreted to represent the peak timing of a regional metamorphism that occurred in the Zuoquan complex due to four reasons: (1) Type 1 and 2 CL imaging of the metamorphic zircons are characterized by zircons extracted from sample CZ23 and those from samples CZ22, CZ28, and CZ34, respectively; (2) the negative europium anomalies and flat HREE patterns of zircons from samples CZ28 and CZ34 are most consistent with the grains having formed or been extensively modified during metamorphism and growth with garnet and plagioclase; (3) petrographic studies indicate that the garnet and plagioclase formed together with the matrix minerals quartz, kyanite, and biotite in samples CZ28 and CZ34; and (4) more than 250 zircon grains were separated from each sample, but petrographic observations show that only a few tiny ones are recognized within the garnet porphyroblasts as inclusions. It is hard to separate tiny zircon inclusions from the garnet.

Our previous study [43] reported similar metamorphic ages of 2507-2483 Ma in other types of rocks in the complex, and these ages were believed to represent an earlier thermotectonic event that occurred before the regional metamorphism in this area. This is because that two garnet-bearing gneiss samples recorded metamorphic ages of $2507 \pm 15 \mathrm{Ma}$ and $2483 \pm 9 \mathrm{Ma}$, respectively, and analyzed metamorphic zircons showed a steep HREE pattern, indicating that they formed before the garnets and peak assemblages [43]. Combined with this study, the interpretation of these metamorphic ages should be updated. They clearly represent the same regional metamorphic event (defined as Phase I) as the period dated 2477-2462 Ma that was obtained in this study, with a near-peak stage occurring at 2507-2483 Ma and the peak at 2477-2462 Ma. Another group of metamorphic ages (1903 $\pm 7 \mathrm{Ma}$ ) was 
only obtained from a garnet-bearing hornblende gneiss sample [43], which was inferred to be the peak or near-peak age of another regional metamorphism (defined as Phase II) that occurred both in the Zuoquan and Zanhuang complexes. However, the REE patterns of the metamorphic zircons were not analyzed. Additional studies are needed for specific interpretation.

In contrast, rocks in the Zanhuang complex commonly record c. $1.85 \mathrm{Ga}$ metamorphic ages, as obtained by zircon $\mathrm{U}-\mathrm{Pb}$, monazite $\mathrm{U}-\mathrm{Th}-\mathrm{Pb}$, and mineral ${ }^{40} \mathrm{Ar}-{ }^{39} \mathrm{Ar}$ dating $[12,15,47-51]$. Two meta-sedimentary samples in this study yield two groups of ages, namely, c. $2495 \mathrm{Ma}$ and 1875-1858 Ma. The former was recorded by sample ZZ17-8 and is interpreted to represent an igneous event before the protolith due to the analytical zircon cores (Group 1), showing obvious oscillatory zoning in the CL images, which is typical of magmatic origin [68]. The ages of 1875-1858 Ma were recorded by samples ZZ17-8 and ZZ29-2. They are suggested to be the peak timing of an extensive metamorphism (Phase II) that occurred in the Zanhuang complex, mainly because (1) the CL images of the analytical zircons (Group 2) show a relatively homogeneous internal texture or blurred irregular zoning, and these zircons generally have $\mathrm{Th} / \mathrm{U}$ ratios lower than 0.2 , which is indicative of a metamorphic origin; and (2) the levels of HREE enrichment reflect the presence of garnet during growth of the metamorphic zircons.

Similar to the Zuoquan metamorphic complex, another group of metamorphic ages was also recorded by a few samples in the local Zanhuang area. Xiao et al. (2014) [12] reported a metamorphic age of $2507 \pm 15 \mathrm{Ma}$ in a felsic biotite-plagioclase gneiss sample, indicating a metamorphism (Phase I) that occurred earlier than the c. 1.85 Ga metamorphic event in this area. Zhang et al. (2019) [44] obtained a weighted mean age of $2485 \pm 9 \mathrm{Ma}(\mathrm{MSWD}=1.8, \mathrm{n}=3$ ) from a biotite-plagioclase gneiss sample but interpreted it as a metamorphic event that occurred before the protolith formed.

\subsection{Tectonic Implications}

Taken together, there are two phases of metamorphism (Phases I and II) recognized in both the Zuoquan and Zanhuang metamorphic complexes, namely, Phase I metamorphism (c. $2.5 \mathrm{Ga}$ ), which was commonly recorded by the Zuoquan metamorphic rocks, and Phase II metamorphism (c. $1.85 \mathrm{Ga}$ ), which was commonly recorded by the Zanhuang metamorphic rocks.

Similar metamorphic ages of c. $2.5 \mathrm{Ga}$ were mainly obtained from the metamorphic rocks exposed in the Western and Eastern Blocks [16] and references therein. Basement rocks from the two blocks commonly recorded counterclockwise $\mathrm{P}-\mathrm{T}$ metamorphic paths with a near-isobaric cooling retrograde segment, and such paths were generally attributed to magmatic underplating [58,59]. Thus, these ages were proposed to be a consequence of a regional granulite-facies metamorphism, related to the underplating of large amounts of mantle-derived magma occurring in the Western and Eastern Blocks $[2,3,10]$. Our study areas were adjacent to the Eastern Block; thus, we infer that c. $2.5 \mathrm{Ga}$ metamorphic rocks formed and underwent c. 2.5 Ga metamorphism (Phase I) in the Eastern Block and were then tectonically involved in the TNCO before c. $1.97 \mathrm{Ga}$.

A large number of 1.97-1.80 Ga metamorphic ages were reported throughout the TNCO over the past 30 years [11-15] and references therein. All metamorphic complexes exposed in the TNCO recorded clockwise P-T metamorphic paths followed by a near-ITD segment (see review by Xiao et al., 2017 [33]), and such paths were thought to have resulted from subduction, collision, and subsequent uplift $[58,59]$. Therefore, although the timing of the major collision between the Western and Eastern Blocks remains unaddressed, these metamorphic ages are thought to represent the regional metamorphism resulting from the subduction, collision, and uplift during the assembly of the NCC along the TNCO $[2,3,10]$. Zhao et al. (2002) [81] suggested that this entire process occurring between 1.97 and $1.80 \mathrm{Ga}$ in the NCC was a response to the assembly of the supercontinent Columbia during $2.1 \mathrm{Ga}$ and $1.8 \mathrm{Ga}$. It is obvious that the TNCO underwent a prolonged and complicated formation process; there are also some other orogenic belts in northwest Scotland [82] and the Greenville Orogen [83] that occupied a similar prolonged duration. Our previous studies showed that the Zuoquan and Zanhuang metamorphic rocks recorded similar metamorphic reaction microstructures and $\mathrm{P}-\mathrm{T}$ paths at medium-pressure facies 
series conditions $[12,46,56,57]$. This evidence, in combination with geochronological data, suggests that the c. $1.85 \mathrm{Ga}$ metamorphism (Phase II) in the Zuoquan and Zanhuang complexes was related to the collision between the Western and Eastern Blocks. During the collision, a lower peak condition was recorded by Zuoquan metamorphic rocks than Zanhuang rocks [12,46,56,57]. It is inferred that the two complexes were metamorphic products at different crustal depths in a crustal thickening-dominated orogen. The Zanhuang complex was at a deeper level of the crust and experienced a more intense and higher degree of metamorphism during Phase II metamorphism. Therefore, the mineral compositions and assemblages of the rocks formed during Phase I metamorphism were badly and rarely preserved after Phase II metamorphism in the Zanhuang complex. This is probably one of reasons why the spatial distributions of metamorphic ages were distinct between the two complexes.

\section{Conclusions}

(1) Two groups of metamorphic ages, c. $2.51-2.46 \mathrm{Ga}$ and c. $1.90-1.85 \mathrm{Ga}$, were recorded in Zuoquan and Zanhuang metamorphic rocks, with the former predominating in the Zuoquan complex and the latter in the Zanhuang complex.

(2) The rocks with metamorphic ages of c. 2.51-2.46 Ga in these areas are interpreted to be portions of the Eastern Blocks. They were involved in the TNCO via tectonic reworking during the Paleoproterozoic era and subsequently underwent a regional metamorphism at c. 1.85 Ga.

(3) The regional metamorphism occurring between c. 1.90 and $1.85 \mathrm{Ga}$ in the Zuoquan and Zanhuang areas was a response to the subduction-collision-uplift process between the Western and Eastern Blocks during the period of 1.97-1.80 Ga.

Supplementary Materials: The following are available online at http://www.mdpi.com/2075-163X/9/12/780/s1. Table S1. Zircon U-Th-Pb analytical data of the Zuoquan and Zanhuang metamorphic samples. (a) CZ22; (b) CZ23; (c) CZ28; (d) CZ34; (e) ZZ17-8; (f) ZZ29-2. Table S2. The REE compositions of zircons from the Zuoquan and Zanhuang metamorphic samples. '-C': the core domain of analyzed zircon. (a) CZ22; (b) CZ23; (c) CZ28; (d) CZ34; (e) ZZ17-8; (f) ZZ29-2.

Author Contributions: L.-L.X. and M.-H.C. did the field work and prepared the samples for study. L.-L.X. carried out the analyses and wrote the manuscript.

Funding: This work was supported by the National Natural Science Foundation of China $(41572173,41102120)$, the Opening Foundation of State Key Laboratory of Continental Dynamics, Northwest University (18LCD06), and the Fundamental Research Funds for the Central Universities (2652017299, FRF-AT-18-013).

Conflicts of Interest: The authors declare no conflict of interest.

\section{References}

1. Wu, J.S.; Geng, Y.S.; Shen, Q.H.; Wan, Y.S.; Liu, D.Y.; Song, B. Archean Geological Characteristics and Tectonic Evolution of the Sino-Korean Ancient Super Continental; Geological Publishing House: Beijing, China, 1998; pp. 192-212. (In Chinese)

2. Zhao, G.C.; Wilde, S.A.; Cawood, P.A.; Lu, L.Z. Thermal evolution of the Archaean basement rocks from the eastern part of the North China Craton and its bearing on tectonic setting. Int. Geol. Rev. 1998, 40, 706-721. [CrossRef]

3. Zhao, G.C.; Sun, M.; Wilde, S.A.; Li, S.Z. Neoarchaean to Palaeoproterozoic evolution of the North China Craton: Key issues revisited. Precambrian Res. 2005, 136, 177-202. [CrossRef]

4. Li, J.H.; Qian, X.L.; Huang, X.N.; Liu, S.W. Tectonic framework of North China Block and its cratonization in the early Precambrian. Acta Petrol. Sin. 2000, 16, 1-10. (In Chinese with English Abstract)

5. Kusky, T.M.; Li, J.H. Paleoproterozoic tectonic evolution of the North China Craton. J. Asian Earth Sci. 2003, 22, 23-40. [CrossRef]

6. Faure, M.; Trap, P.; Lin, W.; Monié, P.; Bruguier, O. The formation of the North China Craton by two Palaeoproterozoic continental collisions in Lüliang-Hengshan-Wutaishan-Fuping massifs. Episodes 2007, 30, 1-12. [CrossRef] [PubMed]

7. Zhai, M.G. Cratonization and the Ancient North China Continent: A summary and review. Sci. China Earth Sci. 2011, 54, 1110-1120. [CrossRef] 
8. Zhai, M.G.; Santosh, M. The early Precambrian odyssey of the North China Craton: A synoptic overview. Gondwana Res. 2011, 20, 6-25. [CrossRef]

9. Zhai, M.G.; Santosh, M. Metallogeny of the North China Craton: Link with secular changes in the evolving Earth. Gondwana Res. 2013, 24, 275-297. [CrossRef]

10. Zhao, G.C.; Cawood, P.A.; Wilde, S.A.; Sun, M.; Zhang, J.; He, Y.H.; Yin, C.Q. Amalgamation of the North China Craton: Key issues and discussion. Precambrian Res. 2012, 222, 55-76. [CrossRef]

11. Peng, P.; Wang, X.P.; Windley, B.F.; Guo, J.H.; Zhai, M.G.; Li, Y. Spatial distribution of 1950-1800 Ma metamorphic events in the North China Craton: Implications for tectonic subdivision of the craton. Lithos 2014, 202, 250-266. [CrossRef]

12. Xiao, L.L.; Liu, F.L.; Chen, Y. Metamorphic P-T-t paths of the Zanhuang metamorphic complex: Implications for the Paleoproterozoic evolution of the Trans-North China Orogen. Precambrian Res. 2014, 255, $216-235$. [CrossRef]

13. Xiao, L.L.; Liu, F.L. Precambrian metamorphic history of the metamorphic complexes in the Trans-North China Orogen, North China Craton. Acta Petrol. Sin. 2015, 31, 3012-3044. (In Chinese with English Abstract)

14. Tang, L.; Santosh, M. Neoarchean-Paleoproterozoic terrane assembly and Wilson cycle in the North China Craton: An overview from the central segment of the trans-north china orogen. Earth Sci. Rev. 2018, 182, 1-27. [CrossRef]

15. Chen, H.X.; Liu, J.H.; Zhang, Q.W.L.; Wang, H.Y.C.; Wu, C.M. A long-lived tectono-metamorphic event in the late Paleoproterozoic: Evidence from SIMS U-Th-Pb dating of monazite from metapelite in central-south Trans-North China Orogen. Precambrian Res. 2020, 336, 105497, in press. [CrossRef]

16. Zhao, G.C.; Wilde, S.A.; Cawood, P.A.; Sun, M. Archean blocks and their boundaries in the North China Craton: Lithological, geochemical, structural and P-T path constraints and tectonic evolution. Precambrian Res. 2001, 107, 45-73. [CrossRef]

17. Yang, C.H.; Du, L.L.; Ren, L.D.; Song, H.X.; Wan, Y.S.; Xie, H.Q.; Liu, Z.X. The age and petrogenesis of the Xuting Granite in the Zanhuang Complex, Hebei Province: Constraints on the structural evolution of the Trans-North China Orogen, North China Craton. Acta Petrol. Sin. 2011, 27, 1003-1016. (In Chinese with English Abstract)

18. Jiang, Z.S.; Wang, G.D.; Xiao, L.L.; Diwu, C.R.; Lu, J.S.; Wu, C.M. Paleoproterozoic metamorphic P-T-t path and tectonic significance of the Luoning metamorphic complex at the southern terminal of the Trans-North China Orogen, Henan Province. Acta Petrol. Sin. 2011, 27, 3701-3717. (In Chinese with English Abstract)

19. Wang, G.D.; Wang, H.; Chen, H.X.; Lu, J.S.; Xiao, L.L.; Wu, C.M. U-Pb Dating of Zircons from Metamorphic Rocks of the Taihua Metamorphic Complex, Mt. Huashan, Southern Margin of the Trans-North China Orogen. Acta Geol. Sin. 2012, 86, 1541-1551. (In Chinese with English Abstract)

20. Wang, G.D.; Wang, H.; Chen, H.X.; Lu, J.S.; Wu, C.M. Metamorphic evolution and zircon U-Pb geochronology of the Mts. Huashan amphibolites: Insights into the Palaeoproterozoic amalgamation of the North China Craton. Precambrian Res. 2014, 245, 100-114. [CrossRef]

21. Lu, J.S.; Wang, G.D.; Wang, H.; Chen, H.X.; Wu, C.M. Metamorphic PTt paths retrieved from the amphibolites, Lushan terrane, Henan Province and reappraisal of the Paleoproterozoic tectonic evolution of the Trans-North China Orogen. Precambrian Res. 2013, 238, 61-77. [CrossRef]

22. Lu, J.S.; Wang, G.D.; Wang, H.; Chen, H.X.; Wu, C.M. Palaeoproterozoic metamorphic evolution and geochronology of the Wugang block, southeastern terminal of the Trans-North China Orogen. Precambrian Res. 2014, 251, 197-211. [CrossRef]

23. Lu, J.S.; Wang, G.D.; Wang, H.; Chen, H.X.; Peng, T.; Wu, C.M. Zircon SIMS U-Pb geochronology of the Lushan terrane: Dating metamorphism of the southwestern terminal of the Palaeoproterozoic Trans-North China Orogen. Geol. Mag. 2015, 152, 367-377. [CrossRef]

24. Lu, J.S.; Zhai, M.G.; Lu, L.S.; Wang, H.Y.C.; Chen, H.X.; Peng, T.; Wu, C.M.; Zhao, T.P. Metamorphic P-T-t path retrieved from metapelites in the southeastern Taihua metamorphic complex, and the Paleoproterozoic tectonic evolution of the southern North China Craton. J. Asian Earth Sci. 2017, 134, 352-364. [CrossRef]

25. Qian, J.H.; Wei, C.J.; Zhou, X.W.; Zhang, Y.H. Metamorphic P-T paths and new zircon U-Pb age data for garnet-mica schist from the Wutai Group, North China Craton. Precambrian Res. 2013, 233, 282-296. [CrossRef] 
26. Qian, J.H.; Wei, C.J.; Clarke, G.L.; Zhou, X.W. Metamorphic evolution and Zircon ages of Garnetorthoamphibole rocks in southern Hengshan, North China Craton: Insights into the regional Paleoproterozoic P-T-t history. Precambrian Res. 2015, 256, 223-240. [CrossRef]

27. Qian, J.H.; Wei, C.J. P-T-t evolution of garnet amphibolites in the Wutai-Hengshan area, North China Craton: Insights from phase equilibria and geochronology. J. Metamorph. Geol. 2016, 34, 423-446. [CrossRef]

28. Qian, J.H.; Yin, C.Q.; Wei, C.J.; Zhang, J. Two phases of Paleoproterozoic metamorphism in the Zhujiafang ductile shear zone of the Hengshan complex: Insights into the tectonic evolution of the North China Craton. Lithos 2019, 330, 35-54. [CrossRef]

29. Chen, H.X.; Wang, J.; Wang, H.; Wang, G.D.; Peng, T.; Shi, Y.H.; Wu, C.M. Metamorphism and geochronology of the Luoning metamorphic terrane, southern terminal of the Palaeoproterozoic Trans-North China Orogen, North China Craton. Precambrian Res. 2015, 264, 156-178. [CrossRef]

30. Zhang, H.F.; Wang, H.Z.; Santosh, M.; Zhai, M.G. Zircon U-Pb ages of Paleoproterozoic mafic granulites from the Huai'an terrane, North China Craton (NCC): Implications for timing of cratonization and crustal evolution history. Precambrian Res. 2016, 272, 244-263. [CrossRef]

31. Zhang, Y.H.; Wei, C.J.; Lu, M.J.; Zhou, X.W. P-T-t evolution of the high-pressure mafic granulites from northern Hengshan, North China Craton: Insights from phase equilibria and geochronology. Precambrian Res. 2018, 312, 1-15. [CrossRef]

32. Tang, L.; Santosh, M.; Tsunogae, T.; Koizumi, T.; Hu, X.K.; Teng, X.M. Petrology, phase equilibria modelling and zircon $\mathrm{U}-\mathrm{Pb}$ geochronology of Paleoproterozoic mafic granulites from the Fuping complex, north China Craton. J. Metamorph. Geol. 2017, 35, 517-540. [CrossRef]

33. Xiao, L.L.; Clarke, G.; Liu, F.L.; Wu, C.M. Discovery of mafic granulite in the Guandishan area of the Lüliang complex, North China Craton: Age and metamorphic evolution. Precambrian Res. 2017, 303, 604-625. [CrossRef]

34. Xiao, L.L.; Clarke, G.; Liu, F.L.; Lu, J.S. Metamorphic records in the Lüliang metapelites of the Jiehekou Group: Implications for the tectonic evolution of the Trans-North China Orogen, North China Craton. Precambrian Res. 2019, 332, 105415. [CrossRef]

35. Zhao, J.; Gou, L.; Zhang, C.; Guo, A.; Guo, X.; Liu, X. P-T-t path and tectonic significance of pelitic migmatites from the Lüliang complex in Xiyupi area of Trans-North China Orogen, North China Craton. Precambrian Res. 2017, 303, 573-589. [CrossRef]

36. Liao, Y.; Wei, C.J. Ultrahigh-temperature mafic granulite in the Huai'an Complex, North China Craton: Evidence from phase equilibria modelling and amphibole thermometers. Gondwana Res. 2019, 76, 62-76. [CrossRef]

37. Qian, J.H.; Wei, C.J.; Yin, C.Q. Paleoproterozoic P-T-t evolution in the Hengshan-Wutai-Fuping area, North China Craton: Evidence from petrological and geochronological data. Precambrian Res. 2017, 303, 91-104. [CrossRef]

38. Wei, C.J.; Qian, J.H.; Zhou, X.W. Paleoproterozoic crustal evolution of the Hengshan-Wutai-Fuping region, North China Craton. Geosci. Front. 2014, 5, 485-497. [CrossRef]

39. Wei, C.J. Paleoproterozoic metamorphism and tectonic evolution in Wutai-Hengshan region, Trans-North China Orogen. Earth Sci. 2018, 43, 24-43. (In Chinese with English Abstract)

40. Cheng, Y.Q.; Yang, C.H.; Wan, Y.S.; Liu, Z.X.; Zhang, X.P.; Du, L.L.; Zhang, S.G.; Wu, J.S.; Gao, J.F. The Early Precambrian Geology and the Reconstruction of Crustal Rocks Resulted by the Anatexis in Middle-Northern Segment of the Taihang Mountain; Geological Publishing House: Beijing, China, 2004; pp. 144-150. (In Chinese)

41. Liu, S.W.; Lü, Y.J.; Feng, Y.G.; Zhang, C.; Tian, W.; Yan, Q.R.; Liu, X.M. Geology and Zircon U-Pb Isotopic Chronology of Dantazi Complex, Northern Hebei Province. Geol. J. China Univ. 2007, 13, 484-497. (In Chinese with English Abstract)

42. Liu, D.Y.; Wilde, S.A.; Wan, Y.S.; Wang, S.Y.; Valley, J.W.; Kita, N.; Dong, C.Y.; Xie, H.Q.; Yang, C.X.; Zhang, Y.X.; et al. Combined $\mathrm{U}-\mathrm{Pb}$, hafnium and oxygen isotope analysis of zircons from meta-igneous rocks in the southern North China Craton reveal multiple events in the Late Mesoarchean-Early Neoarchean. Chem. Geol. 2009, 261, 140-154. [CrossRef]

43. Xiao, L.L.; Liu, F.L.; Zhang, J. Records and its geological implication of metamorphic ages of ca. 2.5 Ga and ca. 1.9 Ga from the Zuoquan metamorphic complex in the Trans-North China Orogen. Acta Petrol. Sin. 2019, 35, 969-988. (In Chinese with English Abstract) 
44. Zhang, F.; Wang, Y.B.; Yang, C.H.; Du, L.L.; Yuan, H.Q. Shrimp U-Pb zircon dating of clastic sedimentary rocks of the Guandu Group, Zanhuang Complex, Hebei Province, and its geological significance. Geol. Bull. China 2019, 38, 1335-1343. (In Chinese with English Abstract)

45. Zhang, F.; Wang, Y.B.; Du, L.L.; Yang, C.H.; Ayers, J.C.; Yuan, H.Q. The Neoarchean-Paleoproterozoic volcanic-sedimentary rocks in the Zanhuang Complex, North China Craton: Petrogenesis and implications for tectonic evolution. Precambrian Res. 2019, 328, 64-80. [CrossRef]

46. Xiao, L.L.; Wu, C.M.; Zhao, G.C.; Guo, J.H.; Ren, L.D. Metamorphic P-T paths of the Zanhuang amphibolitic gneisses and metapelitic gneisses: Constraints on the tectonic evolution of the Paleoproterozoic Trans-North China Orogen. Int. J. Earth Sci. 2011, 100, 717-739. [CrossRef]

47. Xiao, L.L.; Wang, G.D.; Wang, H.; Jiang, Z.S.; Diwu, C.R.; Wu, C.M. Zircon U-Pb geochronology of the Zanhuang metamorphic complex: Reappraisal of the Palaeoproterozoic amalgamation of the Trans-North China Orogen. Geol. Mag. 2013, 150, 756-764. [CrossRef]

48. Wang, Y.J.; Fan, W.M.; Guo, F.; Li, C.W. Biotite ${ }^{40} \mathrm{Ar} /{ }^{39} \mathrm{Ar}$ geochronology of the deformational rocks from Zanhuang metamorphic domain in southern Taihang mountains and their tectonothermal overprinting. Acta Petrol. Sin. 2003, 19, 131-140. (In Chinese with English Abstract)

49. Wang, Y.J.; Fan, W.M.; Zhang, Y.; Guo, F. Structural evolution and ${ }^{40} \mathrm{Ar} /{ }^{39} \mathrm{Ar}$ dating of the Zanhuang metamorphic domain in the North China Craton: Constraints on Paleoproterozoic tectonothermal overprinting. Precambrian Res. 2003, 122, 159-182. [CrossRef]

50. Trap, P.; Faure, M.; Lin, W.; Monié, P.; Meffre, S.; Melletton, J. The Zanhuang Massif, the second and eastern suture zone of the Paleoproterozoic Trans-North China Orogen. Precambrian Res. 2009, 172, 80-98. [CrossRef]

51. Ning, W.B.; Wang, J.P.; Xiao, D.; Li, F.F.; Huang, B.; Fu, D. Electron Probe Microanalysis of Monazite and Its Applications to U-Th-Pb Dating of Geological Samples. J. Earth Sci. 2019, 30, 952-963. [CrossRef]

52. HBGMR. Regional Geology of Beijing, Tianjin and Heibei Province; Geology Publishing House: Beijing, China, 1989; pp. 16-30. (In Chinese)

53. Yang, C.H.; Du, L.L.; Ren, L.D.; Song, H.X.; Wan, Y.S.; Xie, H.Q.; Geng, Y.S. Delineation of the ca. 2.7 Ga TTG gneisses in the Zanhuang Complex, North China Craton and its geological implications. J. Asian Earth Sci. 2013, 72, 178-189. [CrossRef]

54. Du, L.L.; Yang, C.H.; Wyman, D.A.; Nutman, A.P.; Lu, Z.L.; Song, H.X.; Zhao, L.; Geng, Y.S.; Ren, L.D. Age and depositional setting of the Paleoproterozoic Gantaohe Group in Zanhuang Complex: Constraints from zircon $\mathrm{U}-\mathrm{Pb}$ ages and $\mathrm{Hf}$ isotopes of sandstones and dacite. Precambrian Res. 2016, 286, 59-100. [CrossRef]

55. Liu, C.H.; Zhao, G.C.; Sun, M.; Liu, F.L.; Zhang, J.; Yin, C.Q. Zircons U-Pb and Lu-Hf isotopic and whole-rock geochemical constraints on the Gantaohe Group in the Zanhuang Complex: Implications for the tectonic evolution of the Trans-North China Orogen. Lithos 2012, 146, 80-92. [CrossRef]

56. Xiao, L.L.; Jiang, Z.S.; Wan, G.D.; Wan, Y.S.; Wang, T.; Wu, C.M. Metamorphic reactions and metamorphic P-T paths of the Precambrian metamorphic complex, Zanhuang, Hebei, north China. Acta Petrol. Sin. 2011, 27, 980-1002. (In Chinese with English Abstract)

57. Xiao, L.L.; Liu, F.L.; Xie, Y.L.; Wu, C.M. Precambrian metamorphic evolution and its tectonic implications of the Zuoquan metamorphic complex. Acta Petrol. Sin. 2014, 30, 2925-2940. (In Chinese with English Abstract)

58. Ernst, W.G. Tectonic history of subduction zones inferred from retrograde blueschist P-T paths. Geology 1988, 16, 1081-1084. [CrossRef]

59. Brown, M. P-T-t evolution of orogenic belts and the causes of regional metamorphism. J. Geol. Soc. 1993, 150, 227-241. [CrossRef]

60. Li, S.S.; Santosh, M.; Teng, X.M.; He, X.F. Paleoproterozoic arc-continent collision in the North China Craton: Evidence from the Zanhuang Complex. Precambrian Res. 2016, 286, 281-305. [CrossRef]

61. Tang, L.; Santosh, M.; Tsunogae, T.; Maruoka, T. Paleoproterozoic meta-carbonates from the central segment of the Trans-North China Orogen: Zircon $\mathrm{U}-\mathrm{Pb}$ geochronology, geochemistry, and carbon and oxygen isotopes. Precambrian Res. 2016, 284, 14-29. [CrossRef]

62. Xiao, L.L.; Liu, F.L.; Zhang, J. Response to the early Neoarchean tectono-thermal events in the North China Craton: Evidence of ca. 2.7 Ga TTG gneisses from the Zuoquan metamorphic complex. Acta Petrol. Sin. 2019, 32, 325-348. (In Chinese with English Abstract)

63. Yang, C.H.; Du, L.L.; Ren, L.D.; Song, H.X.; Wan, Y.S.; Xie, H.Q.; Liu, Z.X. Petrogenesis and geodynamic setting of the Jiandeng potassic granite at the end of the neoarchean in the Zanhuang complex, north China craton. Earth Sci. Front. 2011, 18, 62-78. (In Chinese with English Abstract) 
64. Song, H.X.; Yang, C.H.; Du, L.L.; Ren, L.D.; Geng, Y.S. Delineation of the 2.7 Ga TTG gneisses in Zanhuang Complex, Heibei Province, and its geological significance. Acta Petrol. Sin. 2018, 34, 1599-1611. (In Chinese with English Abstract)

65. Wiedenbeck, M.; Alle, P.; Corfu, F.; Griffin, W.L.; Meier, M.; Oberli, F.; Quadt, A.V.; Roddick, J.C.; Speigel, W. Three natural zircon standards for $\mathrm{U}-\mathrm{Th}-\mathrm{Pb}, \mathrm{Lu}-\mathrm{Hf}$, trace element and REE analyses. Geostand. Newsl. 1995, 19, 1-23. [CrossRef]

66. Jackson, S.E.; Pearson, N.J.; Griffin, W.L.; Belousova, E.A. The application of laser ablation-inductively coupled plasma-mass spectrometry to in situ U-Pb zircon geochronology. Chem. Geol. 2004, 211, 47-69. [CrossRef]

67. Ludwig, K.R. Isoplot 3.0-A Geochronological Toolkit for Microsoft Excel; (Berkeley Geochronology Center, Special Publication; No. 4); Berkeley Geochronology Center: Berkeley, CA, USA, 2003; pp. 1-70.

68. Corfu, F.; Hanchar, J.M.; Hoskin, P.W.O.; Kinny, P. Atlas of zircon textures. Rev. Mineral. Geochem. 2003, 53, 469-500. [CrossRef]

69. Hoskin, P.W.O.; Schaltegger, U. The composition of zircon and igneous and metamorphic petrogenesis. Rev. Mineral. Geochem. 2003, 53, 27-62. [CrossRef]

70. Harley, S.L.; Kelly, N.M.; Moller, A. Zircon behaviour and the thermal histories of mountain chains. Elements 2007, 3, 25-30. [CrossRef]

71. Taylor, R.J.M.; Kirkland, C.L.; Clark, C. Accessories after the facts: Constraining the timing, duration and conditions of high-temperature metamorphic processes. Lithos 2016, 264, 239-257. [CrossRef]

72. Rubatto, D. Zircon: The Metamorphic Mineral. Rev. Mineral. Geochem. 2017, 83, 261-295. [CrossRef]

73. Rubatto, D.; Hermann, J. Zircon behaviour in deeply subducted rocks. Elements 2007, 3, 31-35. [CrossRef]

74. Hoskin, P.W.O.; Black, L.P. Metamorphic zircon formation by solid-state recrystallization of protolith igneous zircon. J. Metamorph. Geol. 2000, 18, 423-439. [CrossRef]

75. Hermann, J.; Rubatto, D. Relating zircon and monazite domains to garnet growth zones: Age and duration of granulite facies metamorphism in the Val Malenco lower crust. J. Metamorph. Geol. 2003, 21, 833-852. [CrossRef]

76. McKay, G.; Le, L.; Wagstaff, J.; Crozaz, G. Experimental partitioning of rare earth elements and strontium: Constraints on petrogenesis and redox conditions during crystallization of Antarctic angrite Lewis Cliff 86010. Geochim. Cosmochim. Acta 1994, 58, 2911-2919. [CrossRef]

77. Vavra, G.; Gebauer, D.; Schmidt, R.; Compston, W. Multiple zircon growth and recrystallization during polyphase Late Carboniferous to Triassic metamorphism in granulites of the Ivrea Zone (Southern Alps): An ion microprobe (SHRIMP) study. Contrib. Mineral. Petrol. 1996, 122, 337-358. [CrossRef]

78. Schaltegger, U.; Fanning, C.M.; Günther, D.; Maurin, J.C.; Schulmann, K.; Gebauer, D. Growth, annealing and recrystallization of zircon and preservation of monazite in high-grade metamorphism: Conventional and in-situ U-Pb isotope, cathodoluminescence and microchemical evidence. Contrib. Mineral. Petrol. 1999, 134, 186-201. [CrossRef]

79. Kelly, N.; Harley, S. An integrated microtextural and chemical approach to zircon geochronology: Refining the Archean history of the Napier Complex, east Antarctica. Contrib. Mineral. Petrol. 2005, 149, 57-84. [CrossRef]

80. Li, Z.; Wei, C.J.; Zhang, S.W.; Yang, C.; Duan, Z.Z. Neoarchean granitoid gneisses in Eastern Hebei, North China Craton: Revisited. Precambrian Res. 2019, 324, 62-85. [CrossRef]

81. Zhao, G.; Cawood, P.A.; Wilde, S.A.; Sun, M. Review of global 2.1-1.8 Ga orogens: Implications for a pre-Rodinia supercontinent. Earth Sci. Rev. 2002, 59, 125-162. [CrossRef]

82. MacDonald, J.; Wheeler, J.; Goodenough, K.; Harley, S.; Crowley, Q.; Mariani, E. Combined SIMS U-Pb ages and Ti-in-zircon geothermometry fingerprints long deep crustal residence in the Archaean. Mineral. Mag. 2011, 75, 1377.

83. Jamieson, R.A.; Beaumont, C. Coeval thrusting and extension during lower crustal ductile flow-implications for exhumation of high-grade metamorphic rocks. J. Metamorph. Geol. 2011, 29, 33-51. [CrossRef]

(C) 2019 by the authors. Licensee MDPI, Basel, Switzerland. This article is an open access article distributed under the terms and conditions of the Creative Commons Attribution (CC BY) license (http://creativecommons.org/licenses/by/4.0/). 